\title{
SPECIFICS OF CORPORATE MANAGEMENT IN AGRIBUSINESS IN TRANSITIONAL CONDITIONS
}

\author{
Nada Vignjević-Djordjević ${ }^{1}$, Predrag Jovićević ${ }^{2}$, Stefan Kocićc ${ }^{3}$
}

\begin{abstract}
Summary
Corporate governance in agribusiness describes an agency problem resulting from separation of ownership from control in modern corporations and represents a huge cost to the shareholders. The agency problem is regulated by legal protection of minority shareholders, by constituting the Board of Directors as a Supervisory authority to monitor managers and an active agribusiness market for corporate control in agribusiness (against hostile takeover). These mechanisms are regulated by regulations on securities (at the federal level), corporate law (at the state level), and the corporate statutes, regulations and other Contracting Rules (at the company level). These regulations, laws and decrees actually define distribution of power between shareholders and managers. Such techniques of defense against takeover can be beneficial to shareholders, if managers use them to strengthen the bargaining power and increase the selling price of an agribusiness company. However, if managers use it for preservation of position and for the achievement of personal interests these regulations do not contribute to the realization of shareholders' interests.
\end{abstract}

Keywords: Corporate governance, agency problems, shareholders, agribusiness.

JEL: G32, Q13

\section{Introduction}

The main hypothesis of this study is that quality of corporate governance in agribusiness affects the pricing of shares in the capital market. Stock price is the most important indicator of business of agribusiness joint stock companies because it points to their success and market valuation of the corporation. It is necessary to emphasize that there

1 Nada Vignjević-Djordjević Ph.D., Full Professor, University in Novi Pazar, Vuka Karadžića Street nn., Novi Pazar, Serbia, E-mail: midass@orion.rs

2 Predrag Jovićević Ph.D., Assistant Professor Faculty of Applied Management, Economics and Finance, Cvecarska Street no. 2, Novi Sad, Serbia, Phone: +381 6424741 68, E-mail: prejov@yahoo.com

3 Stefan Kocić, M. A., Belgrade Business School, Belgrade, Phone: +381 641807711 E-mail: stefan.kocic@gmail.com.

EP 2015 (62) 3 (869-879) 
are factors of stock price movement that act at the corporate level and at the level of the economy as a whole, that is, factors that agribusiness corporations have an influence on, and external ones which can't be influenced (Porter, Hatherley, Simon, 2002.). This is the primary reason why the relationship between stock price and cause for those changes are in some cases clearly visible, while in others it is very difficult to link the factors and determine the direction of influence, whether they are external or internal factors of corporate governance in agribusiness.

Still all of the researches that this paper relies on have emphasized the importance of quality of corporate governance in agribusiness for economic performances of corporations and for listing of shares on the capital market. Economic performances of companies depend on the mechanisms of corporate governance, be it on legal protection of shareholders, competitive environment of corporations, ownership structure, corporate regulations, decisions made at shareholders' meetings, board composition, corporate financial policy or hired managers (Chauffour, Maur, 2011).

\section{Methodology and data used}

Governing structure of an agribusiness corporation is not an exogenous value, so in many cases it is difficult to draw causal conclusions. For this reason, the GIM have not set the demand on the direction of causality in agribusiness between corporate governance and business performance (http://www.ecgi.org/). Corporate governance is a variable that can be explained by variations in the performance of operations that are not already built into the market price of the company or other indicators (Berglof, Claessens, 2004).

Index correlations with yield management, firm value and agency costs can be explained in several ways.

1) One explanation, which was given by results of a study, points that corporate governance regulations which reduce shareholders' rights directly create additional expenditure to the shareholders (Shileifer, Vishny, 1997). If the market underestimates these additional costs, the return on stocks may be lower than expected and the value of the firm at the beginning of the observation period could be too high. Higher agency costs might also point to lower operational business performance.

2) Alternative explanation is that managers understand that the future performance of the company will be weak, while investors can't predict that. In this case, managers can create management regulations to protect themselves from blame but these regulations do not always contribute to the creation of additional exclusive agency costs.

3) The third explanation is that corporate governance regulation themselves don't have certain power, but are rather a symptom or a signal of higher agency costs - a signal which is not adequately incorporated into the market price of the shares of a corporation. 
Research is on the example of Central European and Balkan countries, based on a study of about 24 different corporate governance regulations in agribusiness for about 150 companies a year, from the September of 2000 to December of 2005 (http://www. standardandpoors.com). While constructing the management index, the authors have given each firm one point in which there is a regulation that restricts shareholders' rights (which represents an increase of power for managers) (Volk, 2010). The advantage of this index is its transparency and the fact that it can easily be re-calculated, even though it doesn't accurately expresses the relative importance and impact of certain regulations. The authors have not made conclusions on the impact of regulations on the wealth of shareholders or the efficiency of operations, but rather only studied the effect of a given regulation on the balance of power in an agribusiness corporation, while constructing the Index (shareholders-managers).

\section{Quality of corporate governance and equity prices}

U.S. researchers Paul Gompres, Joy Ishii, and Andrew Metrick (Gompers, Ishii, Metrick, 2001) tried to elucidate the relationship between quality of corporate governance and equity prices. Their research was focused on internal mechanisms of corporate governance and the relation of mechanisms with the indicators of performance of corporations. Namely, they studied the influence of corporate governance regulations, which ensured defense against hostile takeover on shareholders' rights. They used 24 corporate governance regulations to formulate an indicator of the "Governance Index" (hereinafter referred to as $\mathrm{G}$ ), in the early nineties, and studied the relationship between this index and company's performance in the future, during the nineties. This research found that there is a strong link between corporate governance and yield per share.

Mass occurrence of hostile takeovers of companies during the eighties has contributed to the adoption of a number of regulations for defense against hostile takeovers in many firms. ${ }^{4}$ At the time, the U.S. enacted new legislations which provided firms additional protection against hostile takeovers. This resulted in large differences between the U.S. corporate governance structures which was characterized by the difference in yield. It turned out that corporations whose shareholders had weaker rights made considerably lower yields, had lower value on the capital market, weaker operating performances, higher cost of capital, and they were often in the line of fire by hostile takeovers.

\section{Mechanisms of corporate governance in agribusiness and functioning of the market against hostile takeover}

Resulting inefficiencies are agency strategy costs of dispersed control referred to as corporate governance cost in agribusiness of capital dispersed control. These costs are proportionally tied to costs of acquisition. Institutions of corporate governance in firms

4 Acceptance of regulations was actually the response of firms on the waves of takeovers. Defensive regulations against hostile takeovers and other corporative regulations which were adopted have decreased shareholders' rights.

EP 2015 (62) 3 (869-879) 
with dispersed control tend to create conditions for effective functioning of the market against hostile takeover. It is important that allocation of formal control rights is in accordance with the rights on cash (one share equals one vote). Another important prerequisite for an efficient market against hostile takeover are high standards of information disclosure, which enable better evaluation of stock prices and activating the market against hostile takeover at a time when a potential attacker notices the inefficiency of a firm's management and set the goals that can be realized through hostile takeover. Reduction of these costs of capital is the primary goal of corporate governance (Shileifer, Johnson, 2004). Corporate control in agribusiness market has contributed to the survival of corporations, despite restrictions imposed by investment, finance and manager's decisions on payment of dividends.

Competitiveness on the product market i.e. the corporation's output directly leads to the failure (bankruptcy) of firms which are unable to meet the demands of this market. Therefore, many studies, as a measure of success of corporations are using sales growth at a certain time period. In addition, competition in the product market is an important factor of management discipline that operates poorly, although the time frame for evaluation of mechanisms of action is very long (Kay, Edwards, Duffy, 2004). Thus, promoting competition on the product market provides a solution in the long run. The influence of this mechanism in the discipline of corporate governance in agribusiness depends on government activities on promoting competitive environment in agribusiness, thus strength of competition in the product market can act as a disciplining mechanism which reduces agency costs (Hunya, 2000).

Ability to repay debt and credit ratings, by rating of institutions which assess businesses of corporations is an important signal to investors about the quality of corporate governance. Best-known agencies that provide this information are Moody's and S \& P (http://www.moodys.com/). Many investors are guided by assessments of these agencies when investing in international capital markets.

Threat of bankruptcy is an important external mechanism of corporate governance in agribusiness which puts pressure on corporate managers to operate responsibly. The threat of bankruptcy exists if managers choose the wrong business policy (in most cases transfer the control to creditors) and it represents one of the main external mechanisms of corporate governance (Shleifer, Johnson, 2004).

These arguments emphasize that managers are aware that optimal operating requires constant maximization of share capital in the situation when product, labor, and takeover markets are fully competitive. Thus, competition is an essential ingredient of corporate governance in agribusiness which even works without the owner's interference in the operation and supervision of the company. However, since the real world markets are not fully competitive, it can be expected that only the competition, as the most important disciplining mechanism of corporate governance in agribusiness can act in the direction of improving quality of corporate control. Systems of corporate governance which represent additional disciplining mechanisms of corporate governance, become 
relevant when the fact that the agency problem is not the only market imperfection is accepted (La Porta, Lopez de Silanes, Shleifer, Vishny, 2001). Without the discipline on competitive markets, the agency problem can be optimally solved by complete contracts in which all of the rights and responsibilities of managers would be specified in detail. Since these types contracts can't be achieved in market conditions without higher costs, the theoretical framework still assumes the existence of imperfect markets and incomplete contracts.

\section{Evaluation and measurement of the quality of corporate governance in agribusiness in the Central European and Balkan region}

Only recent research papers attempted to explain the relationship between the quality of corporate governance and corporate stock prices in the capital market of agribusiness. Studies typically involve developed countries, although there are attempts to define the quality of corporate governance indicators of agribusiness in developing countries and transition economies (Bubić, Hajnrih, 2012). However, the main obstacle is the lack of up to date information, precise methodologies and indicators for specific, key terms. There are econometric studies in this area, for the U.S., Germany, Switzerland, Norway, Finland, therefore, mostly for high-income countries. Among the first attempts to define causal link between corporate governance and equity prices there is an research conducted in 2001. by Gompres, Ishii and Metrick, the NBER ${ }^{5}$ researchers and professors at Harvard and the University of Pennsylvania. Further attempt to define the internal and external mechanisms of corporate governance and equity prices relation in the U.S. was done in an econometric research by Cramers and Nair, professors at the University of New York from April 2004. Main data source for the authors was IRRC 6 , which publishes detailed provision listings for each firm.

In December 2004 Brown and Caylor, state university professors from Georgia, formulated a new index, Gov-Score, which they used to explore the link between corporate governance and firm performance. In Europe, among the first papers, is an attempt of Norwegian researchers Bohren Oyvind and Bernt Arne Odegaard to evaluate the association of corporate governance and economic performance of companies listed at the Norwegian capital market in late 2001. Researchers from ECGI ${ }^{7}$ Drobetz Wolfgang, Andreas Schillhofer and Heinz Zimmermann, have proven the connection between corporate governance and the expected return per share for Germany in 2003. All these studies had similar limitations. The problem, in part, was the fact that corporate governance in agribusiness is a new and unexplored academic area with undeveloped theoretical base. Another problem was the fact that the high-quality data is very difficult to find. Therefore it's not surprising that there is no way to tell which factors maximize the value of corporate governance systems (Shleifer, Johnson, 2004).

5 National Bureau of Economic Research - National Bureau of Economic Research

6 Investor Responsibility Research Center

7 European Institute for Corporate Governance

EP 2015 (62) 3 (869-879) 
Corporate management describes the agency problem which is caused by separation of ownership from control in modern agribusiness corporations and is a huge cost to the shareholders (Mihajlović, 2014). In the U.S., the agency problem is regulated with legal protection of minor shareholders, by forming the Board of Directors as a supervising authority which controls the managers and by an active market for corporate control (hostile takeover). These mechanisms are governed by securities regulation (at the federal level), corporate laws (at the state level), and the corporate statutes, contract regulations and other rules (at company level). These regulations and laws actually define the power distribution between shareholders and managers.

If managers used hostile takeover defense techniques to strengthen the bargaining power and increase the selling price of the company, these techniques would be beneficial to shareholders However, if managers use them to preserve their own positions and as an tool to achieve their own personal interest, the provisions do not contribute to the interests of shareholders (Kroupova, Cervena, Antouskova, 2009). GIM analysis is complementary approach with previous research in this area. GIM is focused on the relationship between a large number of corporate governance provisions in agribusiness, which are determined internally, and on long-term company performance. Their analyzes were done based on literature that examines the impact of national legislation on the value and performance of firms ( La Porta, Lopez de Silanes, Shleifer, Vishny, 2000).

Companies usually sought to apply as many of the provisions, as they could, in the nineties. From a total of 180 correlation pairs $((\mathbf{2 4} * \mathbf{1 5}) / \mathbf{2}=\mathbf{1 8 0})$ established between the provisions of Corporate Governance in agribusiness, 99 pairs are positive, of which 60 are statistically significant. In contrast, from 81 negative correlations there are only 20 statistically significant. This indicates that the there may be significant differences in the distribution of power between shareholders and managers.

The influence of certain corporate governance provisions in agribusiness on the business efficiency and shareholders' wealth is not fully understood. However, despite the debate in the international literature on the effect of poison pills, it is clear that the poisoned pill provides additional leverage to the existing management to resist the actions of major shareholders. If management uses this power reasonably, corporation's wealth will increase. If management uses poison pills in order to achieve personal gain, the value of shares of the corporation will drop. Thus, it is clear that the poisoned pill increases the power of managers and weakens control rights of large shareholders. Other provisions act in a similar fashion and, in most cases are tools that management uses to resist shareholder activism. While most existing provisions indicate an active role of management and an attempt to restrict the rights of shareholders, there is an exception in the case of two clauses: "secret ballot" and "cumulative voting". These provisions are made because of shareholder pressures. Voting by secret ballot or a "vote of confidence" in some agribusiness companies requires the appointment of a third party which will count the votes and it is implied that management is prohibited to learn how each shareholder have cast it's vote. Cumulative voting allows shareholders 
to concentrate their votes, so that a large number of minority shareholders can provide greater impact (Megginson, William, Netter, Chahyadi, 2006). These provisions are generally demanded by shareholders with the possibility to be recalled after proposing by managers. In contrast to the secrecy of voting, none of the other 22 provisions have clear and strong support of shareholders or certain opposition from management. Provisions for cumulative voting and secret voting increase shareholders' rights. Therefore, during the construction of $\mathrm{G}$ for the firm in which these provisions do not exist, one point is added.

Categorization of two regulations in agribusiness, prohibiting green mail and golden parachute, seems ambiguous. Green mail is a situation where a potential hostile attacker of the company, who bought the majority stakes, gives up from takeover by selling the packet of shares to the management of the company which was the subject of takeover by exorbitant, high price.

Shares are purchased from corporate invaders, at a price which is significantly higher than the current market price of shares of the corporation, so that the threat of takeover would be canceled. The existence of this regulation provides additional power to management, when the attacker has accumulated a large number of shares in the share capital (Sheshinski, Lopez Calva, 1999). Thus, the regulation which prohibits the use of green mail reduces the power of managers and increasing shareholder rights. However, green mail is a profitable business for the attackers, so the green mail ban would make the large accumulation big "offensive" participations less profitable, ex ante. The presence of green mail ban is positively correlated with 20 out of 23 regulations and besides that is significantly positively correlated in eight regulations, and not significantly negatively correlated with any regulation. Because many companies have started to use green mail regulation as a defense against takeovers, GIM supports the view that the regulations prohibiting green mail reduce shareholder rights. Golden parachute is a clause in the contract of employment (signed by managers) which provides large cash payments to directors, board members in the case of termination of employment or transfer to another position or in the event of a hostile takeover. This is to protect the top management of the company from hostile takeovers because firing a director would make it very expensive. Although such payments could discourage a hostile takeover by increasing the costs necessary for takeover, it does not prevent the creation of mergers. While the impact of this regulation on the position of management and shareholders' wealth is vague and ambiguous, more important effect is the reduction of shareholders' rights.

In this case, the "right" is the possibility of controlling shareholders at no additional cost for firing the management (Pistor, Martin, Gelfer, 2004). Golden parachutes, as well as regulations prohibiting green mail are highly correlated with all other regulations of defense against hostile takeovers. Of the 23 pairs of correlations with other regulations, 19 were positive, and 11 of these positive correlations were statistically significant, and only one negative correlation was statistically significant. Therefore, GIM seen as a golden parachute restrict the rights of shareholders. 
Table 1: Values which the management index $(\mathrm{G})$ can have

\begin{tabular}{|c|c|c|c|c|c|c|}
\hline & $\begin{array}{c}\text { Management } \\
\text { index: }\end{array}$ & Portfolio: & $\begin{array}{c}\text { Above- } \\
\text { average yield } \\
\text { portfolio }\end{array}$ & $\begin{array}{c}\text { 2005 return on 1\$ } \\
\text { invested for a year } \\
2000 \text { portfolio }\end{array}$ & $\begin{array}{c}\text { Number of } \\
\text { firms in the } \\
\text { year 2000 } \\
\text { portfolio }\end{array}$ & $\begin{array}{c}\text { Number of firms } \\
\text { in the year 2005 } \\
\text { portfolio }\end{array}$ \\
\hline & $(1)$ & $(2)$ & $(3)$ & $(4)$ & $(5)$ & $(6)$ \\
\hline 1. & $\mathrm{G}<5$ & Corporate & $0.29^{*}$ & $7.07 \$$ & 150 & 215 \\
\hline 2. & $\mathrm{G}=6$ & & 0.22 & & 119 & 169 \\
\hline 3. & $\mathrm{G}=7$ & & 0.24 & & 158 & 186 \\
\hline 4. & $\mathrm{G}=8$ & & 0.08 & & 165 & 201 \\
\hline 5. & $\mathrm{G}=9$ & & -0.02 & & 160 & 197 \\
\hline 6. & $\mathrm{G}=10$ & & 0.03 & & 175 & 221 \\
\hline 7. & $\mathrm{G}=11$ & & 0.18 & & 149 & 194 \\
\hline 8. & $\mathrm{G}=12$ & & -0.25 & & 104 & 136 \\
\hline 9. & $\mathrm{G}=13$ & & -0.01 & & 84 & 106 \\
\hline 10. & $\mathrm{G}>14$ & Managerial & $-0.42^{*}$ & $3.39 \$$ & 85 & 83 \\
\hline
\end{tabular}

Source: The work of authors

Column 1 shows ten characteristic values can have G.

Column 2 shows the two extreme portfolios that are analyzed in the study of GIM.

Column 3 and 4 shows above-average returns that can be realized by the portfolio which consists of stocks of firms with ten different values of G.

Column 5 and 6 show the number of firms which were surveyed in the 2000 and 2005 research and the values of $\mathrm{G}$ and that the company had in the years observed.

Management index $(\mathrm{G})$ is the sum of points for each individual clause (or in case of existence or absence of any regulation) and is ranked from 0 to 24 . GIM have divided the values of $G$ into ten groups whose values range from $G<5$, then each individual value for $\mathrm{G}$ from $\mathrm{G}=6$ to $\mathrm{G}=13$, and end with $\mathrm{G}>14$.

We have isolated two extreme portfolios: management and shareholders. Managerial portfolio (Portfolio Management) includes firms with the weakest protection of property rights (which corresponds to the highest power manager) and has values of $\mathrm{G}>14$. These are companies which have more than fourteen corporate governance regulations. Shareholder portfolio includes firms with the strongest protection of property rights (corresponding to the weakest manager power) and has values of $G<$ 5. Therefore, firms with a higher index number (lower part of the table) are located in the "Portfolio Management" and it means they have "highest managerial power" or "weakest shareholder rights"; firms with the lowest value index (upper part of the Table 1) located in "Stock portfolio" which means they have "the lowest manager power " or "strongest shareholder rights." It was noted that of the ten largest companies in the "Stock portfolio" in the year 2000, six remained in the stock portfolio in the year 2005, three have dropped out of the portfolio and have $G=6$, and one is missing from 
the sample. "Portfolio Manager" was more active, with only two of the ten companies with the highest market capitalization, which remained in the same portfolio, the four companies have dropped out of the portfolio with $\mathrm{G}=13$ and three companies have dropped out of the sample observations through mergers or emission of additional species shares (class of stock). If we consider the entire sample of firms is observed that of all the companies that were in the Stock and managerial portfolio in the year 2000, 31\% remained in the same portfolio in the year 2005 .

\section{Conclusion}

The privatization process, which marked the last quarter of the last century, is an effective method of improving the performance of state agribusiness enterprises and government decisions which are driven by developed and developing countries. Healthy corporate structure is a fundamental prerequisite for the success of privatization, both from the standpoint of the government, which wants to sell an agribusiness company, and in terms of potential investors.

In the process of privatization governments generally seek to achieve the same goals: 1) to increase government revenues, 2) to reduce government interference in economic trends, 3) to strengthening economic efficiency, 4) increase competition and 5) provide the development of domestic capital markets.

Numerous studies have confirmed that privatization leads to increased production, improved efficiency and increase of investment in capital and payments of dividends. The roots of corporate governance of agribusiness in developing countries and transition economies lies in privatization initiatives that have strengthened since the end of the seventies and eighties of the twentieth century.

In addition, the scandals associated with corporations withdrew the improvement of corporate governance issues, in developing countries, transition economies and developed economies. This is corporate control in agribusiness due to the center of interest of the international business community and international financial institutions.

\section{References:}

1. Berglof, E., Claessens, S., (2004): Corporate Governance and Enforcement, World Bank Policy Research, Working Paper no. 3409.

2. Bubić, J., Hajnrih, J. (2012): The analyses business performances of agricultural enterprises in Vojvodina during the curent crisis, Economics of agriculture, The Balkan cientific Association of Agrarian Economists, Institute of Agricultural Economics, Academy of Economic Studies, No 2, Belgrade.

3. Chauffour, J. P., Maur, J. C. (2011): Preferential Trade Agreement Policies for Development: A Handbook, The International Bank for Reconstruction and Development, (ISBN: 978-0-8213-8643-9) Washington.

4. European corporate governance institute, (available at: http://www.ecgi.org/).

EP 2015 (62) 3 (869-879) 
5. Gompers, P. A., Ishii, J. L., Metrick, A. (2001): Corporate Governance and Equity Prices, National Bureau of Economic Research Working Paper 8449, Cambridge.

6. Hunya, G. (2000): International Competitiveness Impacts of FDI in CEECs, Vienna Institute for International Economic Studies, Research Reports, No. 268.

7. Kay, R. D., Edwards, W. M., Duffy P. A. (2004): Farm management, V edition, McGraw-Hill, New York.

8. Kroupova, Z., Cervena, G., Antouskova, M. (2009): Tools for Agriculture and Rural Development Policy Evaluation, The Business Review, Cambridge.

9. La Porta, R., Lopez de Silanes, F., Shleifer, A., Vishny, R. (2000): Investor Protection and Corporate Govemance, Journal of Financial Economics, Vol. 58, No. 1-2, pp. 3-27.

10. La Porta, R., Lopez de Silanes, F., Shleifer, A., Vishny, R. (2001): Investor Protection And Corporate Governance, Harvard University Faculty Research Working Paper Series, Harvard.

11. Megginson, L., William, M., Netter, S., Chahyadi, S. (2006): Size and Impact of Privatisation - A Survey of Empirical Studies, Journal for Institutional Comparisons, Vol. 3, No. 1, pp. 48-62.

12. Mihajlović, M. (2014): Menadžment znanja kao factor povećanja efikasnosti organizacije, Oditor, no. 9, pp. 33-38, CEFIS, Beograd, Srbija.

13. Moody's, (available at: http://www.moodys.com/).

14. National bureau of economic research, (available at: http://www.nber.org).

15. Pistor, K., Martin, R., Gelfer, S. (2004) Law and Finance in Transition Economies, European Bank for Reconstruction and Development, Working paper No. 49, pp. 171213.

16. Porter, B., Hatherley, D., Simon J. (2002): Principles of External Auditing, 2th Edition, (ISBN 007-286-12319-5), Cranfield School of Management.

17. Sheshinski, E., Lopez Calva, F. (1999): Privatization and its Benefits: Theory and Evidence, Harvard Institute for International Development Paper No. 698, pp. 54-71.

18. Shileifer, A., Vishny, W. (1997): A Survey of Corporate Governance, The Journal of Finance, The Journal of the American Finance Association, Vol. 52, No. 2, pp. 737 783.

19.Shleifer, A., Johnson, S. (2004): Privatization and Corporate Governance, MIT and Harvard University.

20. Standard and poors, (available at: http://www.standardandpoors.com).

21.Volk, T. (2010): Agriculture in the Western Balkan Countries, Leibniz Institute of Agricultural Development in Central and Eastern Europe, IAMO, Vol. 57. 


\title{
SPECIFIFIČNOSTI KORPORATIVNOG UPRAVLJANJA U AGROBIZNISU U TRANZICIONALNIM USLOVIMA
}

\author{
Nada Vignjević-Djordjević ${ }^{8}$, Predrag Jovićević ${ }^{9}$, Stefan Kocić10
}

\begin{abstract}
Apstrakt
Korporativno upravljanje u agrobizniszu opisuje agencijski problem koji nastaje odvajanjem vlasništva od kontrole u modemoj korporaciji i predstavlja veliki trošak za akcionare. Agencijski problem se reguliše pravnom zaštitom malih akcionara, uspostavljanjem funkcije odbora direktora kao nadzomog organa koji kontroliše menadžere $i$ aktivnim poljoprivrednim tržištem za korporativnu kontrolu (neprijateljsko preuzimanje). Ove mehanizme reguliše regulativa hartija od vrednosti (na saveznom nivou), korporativni zakoni (na državnom nivou), i korporativni statuti, ugovorne odredbe i druga pravila (na nivou firmi). Ove regulative, zakoni i odredbe zapravo definišu raspodelu moći između akcionara i menadžera. Ovakve tehnike odbrane od preuzimanja mogu biti od koristi za akcionare, ukoliko ih menadžeri koriste da bi ojačali pregovaračku moć i povećali prodajnu cenu agrobiznisa. Međutim, ukoliko ih menadžeri koriste radi očuvanja sopstvenih pozicija i ostvarenje ličnih interesa, odredbe ne doprinose ostvarenju interesa akcionara.
\end{abstract}

Ključne reči: Korporativno upravljanje, agencijski problem, akcionari, agrobiznis.

8 Prof. dr Nada Vignjević-Djordjević, Univerzitet u Novom Pazaru, Vuka Karadžića bb, Novi Pazar, Srbija, E-mail: midass@orion.rs

9 Doc. dr Predrag Jovićević, Univerzitet Privredna akademija, Fakultet za primenjeni menadžment, ekonomiju i finansije, Cvećarska br. 2, Novi Sad, Srbija, Telefon: +381 64 24741 68, E-mail: prejov@yahoo.com

10 Master Stefan Kocić, Beogradska poslovna škola, Telefon: +381 641807711 E-mail: stefan.kocic@gmail.com.

EP 2015 (62) 3 (869-879) 